\title{
Homeopathy: a possible weapon against multidrug- resistant bacteria to antibiotics
}

\author{
Ana Paula Macedo de Souza ${ }^{2}$, Leandro Ribeiro Bissoli ${ }^{1}$, \\ Registila Libania Beltrame ${ }^{1}$, Cidéli de Paula Coelho ${ }^{4}$ Susana Diniz ${ }^{3}$, \\ Tânia Aguiar Passeti ${ }^{1}$
}

(1) Medicine School, University of ABC - Santo André, Brazil

(2) Medicine School, University of São Camilo - São Paulo, Brazil

(3) Bandeirantes University - São Paulo, Brazil

(4) Santo Amaro University (UNISA), São Paulo, Brazil

\begin{abstract}
Background: The antimicrobial resistance is a genetic phenomenon, related to the existence of the gens restrained in microorganism that codify different biochemical mechanisms that obstruct the drugs actions. Some species present resistance widespread in all over the world, like the case of Staphylococcus aureus. This is one of the main bacteria that, in a period of time, has got multiple resistance against the antibiotics, and it's also, an important agent causative of the nosocomiais infections. The present report evaluated the action of the different homeopathic medicines about the growth of the bacteria Staphylococcus aureus and Staphylococcus aureus MRSA (Methicillin-resistant Staphylococcus aureus) "in vitro". Methods: Doses of 150, 250 and $350 \mu \mathrm{L}$ of the homeopathic medicines Silicea, Hepar sulfor, Belladona, Arnica montana, Mercurio solubilis and nosode of Stafilococcus aureus, in the dynamism $6 \mathrm{cH}, 12 \mathrm{cH}$ e $30 \mathrm{cH}$ had been placed in $3 \mathrm{~mL}$ culture liquid Mueller Hinton. It was added to this blend $10 \mu \mathrm{L}$ of a diluted bacterial solution 1/10, where of the solution in 0,5 of the Macfarley scale in $37^{\circ} \mathrm{C}$, the growth in the tubes was evaluated in Spectrophotometric of $600 \mathrm{~nm}$. Results: The results demonstrated that, for the Staphilococcus aureus, we have got significant bacteria inhibition in about 70 to $90 \%$ of the growth "in vitro", provided by the homeopathic medicines Hepar sulfor in the dynamism of $30 \mathrm{cH}$, Belladona in the dynamisms of $6 \mathrm{cH}$ and $30 \mathrm{cH}$, in the Staphilococcus aureus nosode in the dynamisms $6 \mathrm{cH}$ and $30 \mathrm{cH}$ and Silicea in the dynamism of $\mathrm{CH} 6$, with regard to the control with alcohol 30\%. The Staphilococcus aureus MRSA presented inhibition from 40\% to $20 \%$ of the bacteria growth "in vitro" related to the control with alcohol $30 \%$, with the same medicines used before. Conclusion: We can conclude that the homeopathic medicines have an inhibitory action in the bacteria growth, including in bacteria resistance to the antibiotics. This information can suggest that a concerted action of antibiotics and homeopathic medicines, could improve the action of the antibiotics in the bacteria causative of infections in the biological tissues.
\end{abstract}

Keywords: homeopathic medicines, Stafilococcus aureus and "in vitro"

\section{(cc) EY-NC-ND Licensed to GIRI}

Support: authors declare that this study received no funding

Conflict of interest: authors declare there is no conflict of interest

Received: March 30th 2014; Revised: May 10th 2014; Published: June 30th 2014.

Correspondence author: Tânia Aguiar Passeti, Tania.passeti@japta.com.br.

How to cite this article:. Passeti TA, Souza APM , Bissoli LR, Beltrame RL, Susana Diniz S, Coelho CP, Homeopathy: a possible weapon against multidrug-resistant bacteria to antibiotics.. Int J High Dilution Res [online]. 2014 [cited YYYY Month dd]; 13(47):114-114. Proceedings of the XXVIII GIRI Symposium; 2014 Jun 20-22; Sighisoara (Romania). GIRI; 2014; Available from: http://www.feg.unesp.br/ ojs/index.php/ijhdr/article/view/727/705 